\title{
Diagnosis klinis infeksi herpes zoster (laporan kasus) Clinic diagnosis of herpes zoster (case report)
}

\author{
${ }^{1}$ M. Jusri, ${ }^{2}$ Erni Marlina \\ ${ }^{1}$ Departemen Ilmu Penyakit Mulut Fakultas Kedokteran Gigi Universitas Airlangga, Surabaya \\ ${ }^{2}$ Bagian Ilmu Penyakit Mulut Fakultas Kedokteran Gigi Universitas Hasanuddin, Makassar \\ Indonesia
}

\begin{abstract}
Varicella is the fastest spreading infection. This virus classified as DNA virus with primer infection that caused chicken pox mainly seen in children. Reactivation of this infection causes herpes zoster or shingle. Painfull of area involved proceed the unilateral and segmental nature of disease. If facial involved segmentally, it occurs pain especially at the facial and dentition that sometimes suspect as pulpitis. This case report is aimed to discuss diagnosis and management of herpes zoster with headache. Patient, male, 66 years old came with chief complaint of headache and ulcers on right facial with eat disturbance due to oral cavity pain. The diagnosis was herpes zoster. Patient was prescribed with acyclovir $1600 \mathrm{mg} 4$ times per day, analgesic, antibiotic mouth wash, and vitamins. Oral pain disappeared in 3 days, dan after 3 weeks healed completely. Diagnosis of herpes zoster could be get from detail anamnesis and examination.
\end{abstract}

Key words: herpes zoster, acyclovir, carbamazepin

\begin{abstract}
ABSTRAK
Varicella adalah salah satu virus yang penularannya sangat cepat. Virusnya merupakan golongan virus DNA dan infeksi primernya menyebabkan penyakit chicken pox yang terutama terjadi pada anak-anak. Sedangkan reaktivasi infeksi ini menyebabkan terjadinya herpes zoster atau shingle. Herpes zoster bersifat unilateral dan segmental dan biasanya didahului oleh rasa nyeri yang hebat. Bila mengenai segmen fasial akan timbul rasa nyeri pada wajah dan gigi geligi sehingga sering diduga sebagai pulpitis. Laporan kasus ini bertujuan untuk membahas diagnosis dan tatalaksana kasus herpes zoster yang gejalanya didahului dengan rasa sakit kepala. Pasien adalah seorang laki-laki, 66 tahun datang dengan keluhan sakit kepala dan luka-luka di pipi sebelah kanan, dan rasa sakit di dalam mulut hingga pasien sulit makan. Setelah melalui pemeriksaan didiagnosis sebagai herpes zoster. Pasien diterapi dengan acyclovir $1600 \mathrm{mg}$ sehari yang terbagi dalam 4 dosis, analgesik, dan obat kumur antibiotik serta vitamin. Keluhan di rongga mulut hilang setelah tiga hari, dan pasien sembuh setelah 3 minggu. Dapat ditarik simpulan bahwa diagnosis herpes zoster dapat ditegakkan melalui anamnesis dan pemeriksaan yang teliti.
\end{abstract}

Kata kunci: herpes zoster, acyclovir, carbamazepin

Koresponden: M. Jusri, Departemen Ilmu Penyakit Mulut Fakultas Kedokteran Gigi Universitas Airlangga, Surabaya, J1. Prof. Dr. Moestopo No.47, Surabaya 60286, Indonesia. E-mail:

\section{PENDAHULUAN}

Varicella adalah salah satu infeksi virus yang penularannya sangat cepat. ${ }^{1}$ Virus ini merupakan golongan virus DNA dan infeksi primernya menyebabkan penyakit chicken pox yang terutama terjadi pada anak-anak, sedang reaktivasi infeksi ini menyebabkan terjadinya herpes zoster atau shingle. ${ }^{2,3}$ Chicken pox ditularkan melalui infeksi droplet atau kontak langsung dengan pasien yang terinfeksi. Setelah gejala pada kulit atau mukosa membran hilang, virus zoster tetap akan laten di akar dorsal ganglia dan dapat mengalami reaktivasi terutama jika terjadi kondisi imunosupresi atau sejalan dengan usia. Herpes zoster bersifat unilateral dan segmental, dan biasanya didahului oleh rasa nyeri yang hebat. Bila mengenai segmen fasial akan timbul rasa nyeri pada wajah dan gigi-geligi sehingga sering diduga sebagai pulpitis. ${ }^{4-6}$
Insidensi chicken pox sekitar 500.000 kasus pertahun di Amerika, sedangkan di Inggris hanya mencapai setengahnya. Insidensi herpes zoster di Amerika serikat adalah 3-4 kasus per 1000 orang. Insidensi ini meningkat hingga 10 kasus per 1000 orang pada mereka yang berusia 75 tahun atau lebih.

Pada makalah ini akan dilaporkan dan dibahas kasus herpes zoster trigeminal yang gejalanya didahului dengan rasa nyeri kepala seperti nyeri gigi.

\section{KASUS}

Pada tanggal 3 Februari 2009 seorang pasien laki-laki yang berusia 66 tahun datang dengan keluhan sakit kepala dan munculnya luka-luka di pipi sebelah kanan hingga ke telinga. Rasa nyeri berlangsung selama satu minggu. Sebelumnya pasien merasa gigi belakang kanan bawahnya 
terasa nyeri hingga ke kepala. Pasien minum obat penghilang nyeri, sakit giginya hilang namun sakit kepala semakin terasa, kemudian muncul lukaluka di pipi kanan tersebut. Rasa nyeri juga mengenai rongga mulut hingga sulit makan, dan hanya bisa minum. Menurut pasien, pada saat munculnya sakit gigi, pasien merasa demam, meriang dan lemas, yang mungkin disebabkan oleh nyeri yang hebat pada giginya.

Pada pemeriksan ekstra oral tampak pustula, ulserasi, krusta dan edema di daerah fasial kanan hingga ke telinga kanan. Ulserasi, krusta dan edema juga mengenai daerah labial bawah sebelah kanan. nodus limfe submandibula kanan membesar dan teraba lunak. Pemeriksaan intra oral tampak ulser multipel pada daerah ventral dan dorsal lingual serta di dasar lidah sebelah kanan (Gambar 1). Ulser berjumlah sekitar 20 dengan diameter 0,1-4 $\mathrm{mm}$, dan pseudomembran putih kekuningan di kelilingi daerah eritema. Juga dijumpai pseudomembran putih, bisa dikerok sepanjang sisi kiri frenulum lingual. Pada mukosa labial bawah dan bukal kanan tampak ulser multipel kira-kira 20 ulser berdiameter 2-8 mm dengan pseudomembran putih kekuningan dikelilingi oleh daerah eritema, memanjang dari daerah mukosa labial hingga bukal daerah molar ketiga.

Riwayat kesehatan umum tidak ada kelainan.
Pasien juga tidak mengetahui apakah sebelumnya pernah menderita penyakit chicken pox.

Dari anamnesis dan gambaran klinis, kasus ini kemudian didiagnosis sebagai herpes zoster.

\section{TATALAKSANA}

Terapi yang diberikan berupa kausatif, simptomatik, suportif dan preventif. Terapi kausatif, yaitu acyclovir 4 × $400 \mathrm{mg}$ selama 2 minggu. Terapi simptomatis berupa analgesik, asam mefenamat 3 x $500 \mathrm{mg}$, yang kemudian diganti dengan carbamazepin 3 x $200 \mathrm{mg}$. Pada wajah diberikan bedak salisilat topikal. Terapi suportif berupa obat kumur dibuat dengan cara melarutkan 10 kapsul tetracycline $250 \mathrm{mg}$ dalam $10 \mathrm{ml}$ air, dan bedak salysilat yang ditaburkan ke daerah lesi, serta multivitamin yang meliputi tablet vitamin B komplek yang mengandung zinc $1 \mathrm{x}$ perhari selama 5 hari dan suplemen makanan.

Untuk mencegah penyebaran virus ini kepada orang lain, atau keluarganya, pasien diminta untuk sedapat mungkin mengisolasi diri terutama dari anak kecil. Pasien diminta untuk kontrol 4 hari kemudian.

Hari ketiga sejak kunjungan pertama, rasa nyeri di rongga mulut telah hilang, tapi rasa nyeri di kepala tidak ada perubahan. Pasien sudah bisa makan makanan lunak. Rasa bengkak di pipi berkurang, luka di pipi sudah mengering.
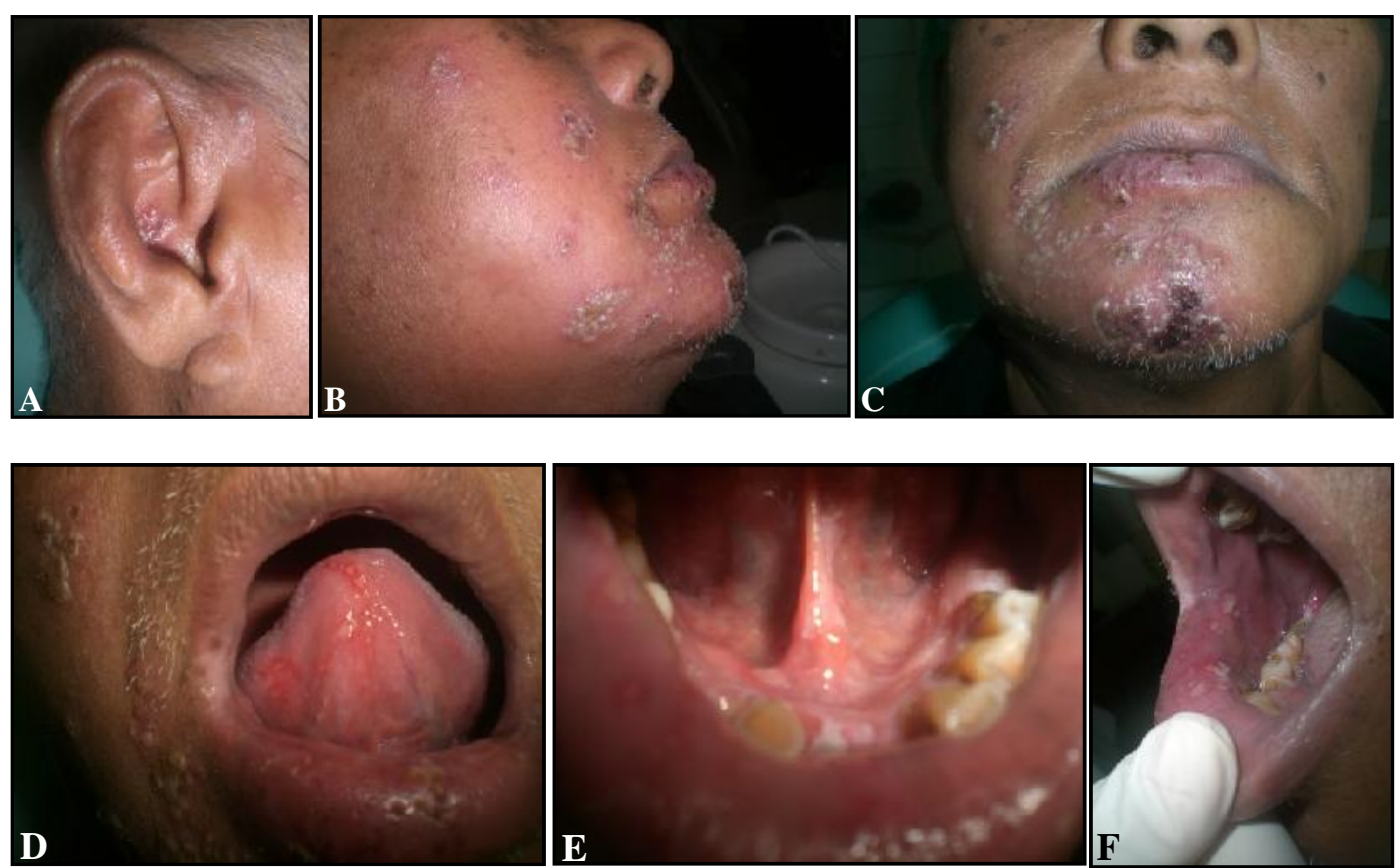

Gambar 1. Tampakan klinik ekstra oral pada kunjungan pertama: pustula, krusta dan edema di A. telinga luar kanan, B. pipi hingga ke dagu kanan, C. pipi hingga dagu kanan. Intra oral: D. ulserasi di ventral lidah kanan, dan di labial bawah kanan, E. ulserasi di dasar mulut kanan, pseudomembran putih dapat dikerok di frenulum kiri, F. ulserasi sepanjang mukosa bukal kanan hingga ke bukal kanan sekitar daerah molar ketiga. 


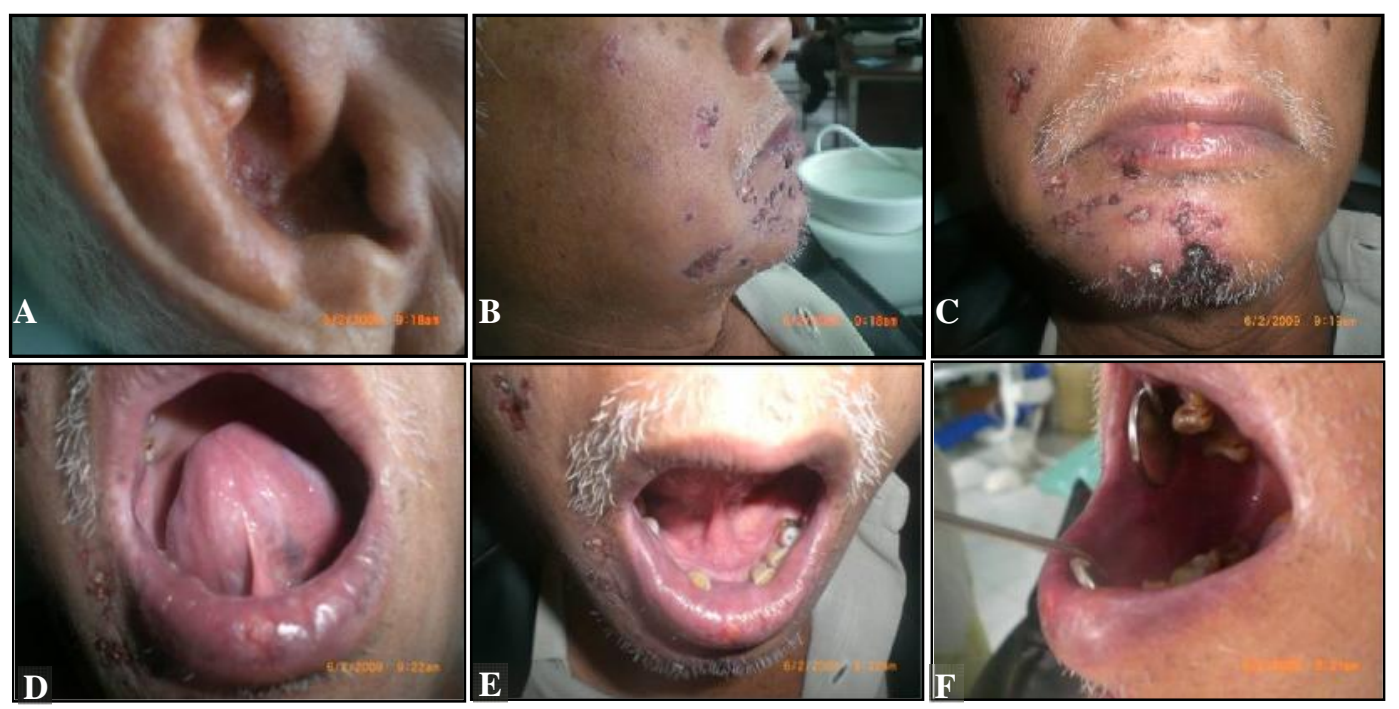

Gambar 2. Tampakan ekstra oral 3 hari sejak kunjungan pertama: A. Pustula, krusta dan edema masih dijumpai pada telinga kanan, B. pustula didagu dan pipi kanan sudah tidak ada, tinggal krusta dan edema, C. ulserasi di ventral kanan lingual sudah tidak ada, tinggal ulserasi di labial bawah kanan, D. ulserasi di dasar mulut kanan, pseudomembran putih dapat dikerok di frenulum kiri, E dan F. ulserasi sepanjang mukosa bukal kanan hingga ke bukal kanan sekitar daerah molar ketiga.

Pada pemeriksaan ekstra oral fasial kanan nampak krusta, edema, dan ulserasi pada daerah dagu hingga ke daerah pipi. Pada telinga kanan dalam masih dijumpai adanya pustula, ulserasi dan edema. Ulserasi di labial bawah dengan diameter sekitar $4 \mathrm{~mm}$ dengan pseudomembran putih kekuningan di kelilingi daerah eritema. Juga tampak krusta di batas bibir bawah (Gambar 2).

Pada pemeriksaan intra oral, ulserasi di ventral dan dorsal lidah sudah sembuh, demikian juga di sepanjang mukosa labial kiri hingga ke mukosa bukal, dan dasar lidah. Pseudomembran putih di sebelah kiri frenulum lidah juga sudah hilang.

Prinsip terapi masih sama dengan kunjungan pertama, yaitu terapi kausatif, terapi simptomatis dan suportif, serta preventif. Acyclovir dilanjutkan dengan dosis yang sama yaitu 4 x $400 \mathrm{mg}$ tablet untuk 10 hari. Asam mefenamat diganti dengan carbamazepin $200 \mathrm{mg}, 3 \times 1 / 2$ sebanyak 6 tablet untuk 4 hari dengan instruksi jika meminum setengah tablet pertama pasien merasa agak pusing, mual, atau merasa ada kelainan maka obat harus dihentikan. Tetracycline kumur dilanjutkan, dan vitamin $\mathrm{B}$ komplek yang mengandung zinc diganti dengan vitamin $\mathrm{B} 1, \mathrm{~B} 6$, dan $\mathrm{B} 12$ yang mengandung parasetamol $500 \mathrm{mg}, 1 \mathrm{x}$ perhari selama 5 hari.

Pasien diinstruksikan agar daerah edema diupayakan tetap kering, jangan sampai terkena air. Pasien diminta untuk kontrol 3 hari lagi.

Pada hari ketujuh sejak kunjungan pertama, pasien masih merasa nyeri di ujung lidah dan telinga kanan terasa cekot-cekot. Pada pemeriksaan ekstraoral masih dijumpai adanya krusta di daerah fasial kanan mulai dari pipi hingga dagu, dan pada telinga kanan. Pemeriksaan intraoral menunjukkan adanya daerah eritema
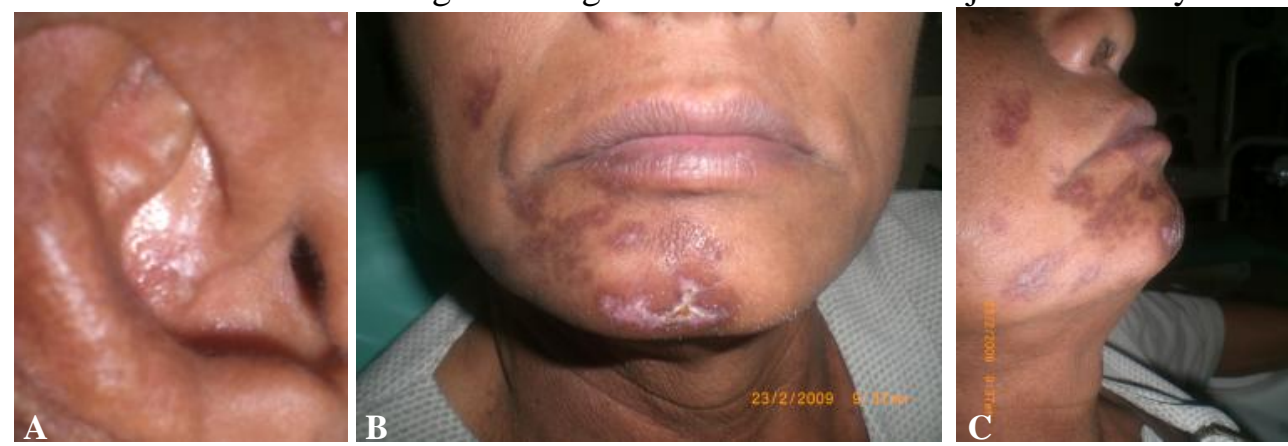

Gambar 3. Gambaran klinik ekstra oral pada kunjungan keempat, minggu ketiga sejak kunjungan pertama: A. lesi di telinga kanan sembuh, B dan C. patch dan scar lesi sebelumnya. 
berdiameter sekitar $3 \mathrm{~mm}$ di anterior lidah.

Pasien kemudian diresepken acyclovir salep untuk digunakan $3 \mathrm{x}$ sehari pada krusta fasial kanan, dan diberikan vitamin B komplek yang mengandung zinc $1 \mathrm{x}$ sehari untuk sepuluh hari. Pasien dirujuk ke THT untuk mengatasi krusta dan edema di daerah telinga. Pasien diminta kontrol 10 hari kemudian.

Pada hari ke-20 atau sekitar minggu ketiga, pasien memberitahukan bahwa saat memeriksakan telinganya ke dokter THT, pasien tidak diberikan terapi apapun karena sudah ada obat sebelumnya. Pasien diminta tetap melanjutkan terapi dari dokter gigi. Keluhan pada telinga pasien sudah hilang. Tinggal bekas luka di daerah fasial yang terasa mengganggu (Gambar 3). Untuk itu, pasien kemudian dirujuk ke Klinik Kulit Kelamin.

\section{PEMBAHASAN}

Herpes zoster (HZ) merupakan penyakit reaktifasi virus varicella yang bersifat laten pada akar dorsal ganglion. Virus varicella sendiri merupakan golongan virus herpes yang memiliki nukleus deoxyribonucleic acid (DNA). Herpes zoster didahului dengan masa prodromal 2-4 hari dengan nyeri hebat, parastesia, sensasi terbakar, dan rasa kaku sepanjang daerah persarafan yang terkena. Dapat dijumpai kelompok vesikula unilateral dengan dasar eritema, sepanjang daerah yang dipersarafi yang memberikan gambaran klinis khas. Vesikula akan pecah dan mengering dalam seminggu, lalu sembuh dalam 2-3 minggu. Saraf yang paling sering terkena adalah C3, T5, $\mathrm{L} 1, \mathrm{~L} 2$, dan N. trigeminalis divisi satu. ${ }^{2,7}$

Pada kasus ini, diagnosis ditegakkan berdasarkan kondisi umum, anamnesis dan pemeriksaan ekstra dan intra oral. Anamnesis jelas menunjukkan adanya riwayat prodromal berupa demam, meriang, dan terasa lemas yang merupakan gejala terjadinya infeksi. Gambaran klinis yang khas yaitu ulser, edema, dan pustula pada daerah sepanjang distribusi persarafan N.trigeminalis menjadikan diagnosis klinis cukup akurat. ${ }^{8}$ Demikian pula pada kasus ini, dijumpai adanya ulserasi unilateral dan lesi kulit hanya terjadi pada daerah persarafan N.trigeminalis sehingga diagnosisnya adalah herpes zoster.

N.trigeminalis divisi maksila adalah cabang sensoris yang mensuplai kulit hingga sebagian tengah wajah, di bawah kelopak mata, sisi hidung, bibir atas, mukosa membran nasofaring, sinus maksilaris, palatum lunak, dan gigi. Salah satu cabang terminalnya adalah n.palatinalis yang besar yang mensuplai palatum keras, sebagian gingiva rahang atas, uvula, dan sebagian palatum lunak. Cabang lainnya adalah n.alveolaris superior yang mensuplai gingiva rahang atas, gigi, dan mukosa membran pipi. ${ }^{8}$

Jika infeksi herpes zoster mengenai N.trigeminalis divisi mandibula atau maksila maka pasien akan mengalami rasa nyeri hingga ke kepala seperti rasa nyeri odontogen. Rasa nyeri ini biasanya timbul sebelum munculnya lesi kutan yang khas, karena itu sering salah didiagnosis sebagai nyeri odontogen. Hal ini seperti yang dilaporkan oleh Harijanti dkk mengenai seorang pasien yang datang ke puskesmas dengan keluhan sakit gigi yang kemudian dirawat konservasi namun nyeri gigi tidak berkurang. Perawatan diberikan tanpa mengabaikan adanya edema dan eritema di fasial kiri pasien. ${ }^{8}$ Hal yang sama dilaporkan oleh Sigurdsson dkk mengenai seorang pasien yang datang dengan keluhan rasa sakit yang menyebabkan pasien tidak bisa tidur selama 2 malam. Rasa sakit terkadang menyebar kebagian atas mata dan telinga, akan tetapi analgesik hanya sedikit menghilangkan rasa sakit. Pada pemeriksaan intra dan ekstra oral tidak dijumpai lesi sehingga kasus didiagnosis sebagai pulpitis dan pasien dirujuk untuk melakukan perawatan endodonsia. Setelah tiga hari, pasien kembali dengan mengeluhkan munculnya bulla dan pembengkakan di daerah fasial kanan disertai rasa nyeri yang intensitasnya makin hebat di atas telinga. ${ }^{9}$ Dari laporan ini beserta banyak laporan lain mengenai kesalahan mendiagnosis herpes zoster bahkan ketika lesi yang khas sudah dapat dilihat maka sangat diperlukan pengetahuan, anamnesis serta pemeriksaan intra maupun ekstra oral yang teliti. Gambaran khas herpes zoster dengan adanya gejala prodromal, sakit hebat, dan lesi pada salah satu cabang trigeminal mendasari diagnosis klinis ini.

Terapi harus diarahkan untuk memperpendek periode infeksi, mencegah terjadinya komplikasi, mencegah penularan, dan simptomatis. Pasien kemudian diterapi kausatif dengan pemberian acyclovir sebagai agen antivirus $1600 \mathrm{mg}$ per hari sebagai dosis minimal untuk herpes zoster. ${ }^{10}$ Acyclovir atau obat antiherpes keluaran baru lainnya dapat mengurangi nyeri akut, memperpendek durasi shedding virus, dan menghentikan pembentukan lesi baru. Berkurangnya keparahan infeksi akut dan kerusakan saraf dengan pemberian antivirus ini nampaknya dapat mengurangi terjadinya komplikasi herpes zoster yaitu post herpetic neuralgia. ${ }^{6,8}$ 
Terapi simptomatis yang diberikan adalah asam mefenamat yang diharapkan mampu mengurangi rasa nyeri. Sedang tetracycline topikal diharapkan mampu mempercepat penyembuhan lesi intraoral melalui efek penghambatan matriks metaloproteinasenya yang menyebaban terjadinya proses kerusakan jaringan. Selain itu tetracycline kumur dapat mencegah semakin parahnya lesi oral dengan kandungan antibiotiknya sehingga infeksi sekunder dapat dihindari. Bedak salisilat membantu menekan inflamasi dari luar.

Pada kontrol pertama, tiga hari sejak kunjungan pertama, sakit kepala masih terasa, bengkak di pipi berkurang dan mengering. Pemeriksana intraoral menunjukkan semua lesi sebelumnya telah sembuh, dan tidak ada kelainan. Pemberian acyclovir dilanjutkan sedang analgesik yang lebih kuat diberikan berupa carbamazepin dan parasetamol $500 \mathrm{mg}$ kombinasi dengan vitamin B1, B6, dan B12 yang diperlukan untuk membantu perbaikan saraf.

Pada hari ketujuh sejak kunjungan pertama, masih terasa sedikit nyeri di lidah. Meski sebelumnnya tidak mengeluhkan rasa nyeri di lidah, namun nyeri ini kemungkinan berasal dari sisa lesi terdahulu dan bukan merupakan lesi baru yang kurang dirasakan oleh karena banyaknya lesi ulserasi lain yang lebih menyebabkan rasa nyeri seperti pada daerah fasial atau lesi lain di rongga mulut yang lebih parah. Menurut referensi, lesi intra dan ekstra oral akan sembuh dalam jangka waktu 2-4 minggu atau lebih. ${ }^{6}$ Rasa cekot-cekot di daerah telinga dirujuk ke THT.

Pada hari ke-20 dari kunjungan pertama, rasa nyeri sudah tidak ada tinggal sisa bekas lesi di fasial kanan. Meskipun lesi intra oral atau ekstra oral diharapkan dapat sembuh dalam 4 minggu, ${ }^{9}$ namun karena estetik yang cukup mengganggu pasien maka pasien dirujuk ke Bagian Kulit
Kelamin. Pasien dianggap sembuh dan diminta kontrol jika ada keluhan lain.

\section{SIMPULAN}

Seorang dokter gigi harus teliti dalam melakukan anamnesis dan memeriksa keluhan nyeri odontogen pasien. Diagnosis herpes zoster dapat ditegakkan melalui anamnesis dan pemeriksaan yang teliti.

\section{DAFTAR PUSTAKA}

1. Asano Y. Clinicopathologic understanding and kontrol of varicella-zoster virus infection. Vaccina 2008; 26: 6487-90.

2. Lynch AM, Brightman JV, Greenberg SM. Burket: Ilmu penyakit mulut. $8^{\text {th }}$ Ed. Jakarta: Bina Rupa Aksara; 2003. P. 67-84.

3. Reiss SC. Neurotropic viral infection. Cambridge: Cambridge University; 2008. p.22-3.

4. Spruance LS, Kriesel DJ, Evans GT, McKeough MB. Susceptibility to herpes labialis following multiple experimental exposures to ultraviolet radiation. Antiviral Res 1995; 28: 57-67.

5. Gnan JW, Whitley RJ. Herpes zoster. The New Engl J Med 2002; 347(5): 340-6.

6. Field A, Longman L. Tyldesley's oral medicine. $5^{\text {th }}$ Ed. New York: Oxford University Press; 2003.p. 42-3.

7. Macaladad N, Marcano T, Guzman M. safety and immunogenicity of zoster vaccine in varicellazoster virus seronegative and low-seropositive healthy adults. Vaccine 2007; 25: 2139-44.

8. Harijanti K, Setyaningtyas D, Isidora KS. The management of oral candidosis in diabetic patients with maxillary herpes zoster. Dent J 2008; 41: 1326.

9. Sigurdsson A, Jacoway RJ. Herpes zoster infection presenting as an acute pulpitis. Oral Surg Oral Med Oral Pathol Oral Radiol Endod 1995; 80:92-5.

10. Laskaris G. Treatment of oral diseases. $3^{\text {rd }} \mathrm{Ed}$. Stutgart: Thieme; 2003.p.66-7. 